\title{
Understanding the Ecology of Restored Fen Peatlands for Protection and Sustainable Use
}

\author{
Nicole Wrage-Mönnig ${ }^{1, * \mathbb{D}}$ and Peter Leinweber ${ }^{2}$ \\ 1 Grassland and Fodder Sciences, Faculty of Agricultural and Environmental Sciences, University of Rostock, \\ J.-v.-Liebig-Weg 6, 18051 Rostock, Germany \\ 2 Soil Science, Faculty of Agricultural and Environmental Sciences, University of Rostock, J.-v.-Liebig-Weg 6, \\ 18051 Rostock, Germany; peter.leinweber@uni-rostock.de \\ * Correspondence: nicole.wrage-moennig@uni-rostock.de
}

Received: 3 April 2020; Accepted: 15 April 2020; Published: 21 April 2020

check for updates

\section{Introduction}

Natural peatlands are the most effective terrestrial carbon stock on our planet. However, many peatlands have been artificially drained for agricultural and forestry purposes, or peat extraction. Drainage leads to decomposition and compaction of the peat, and, thus, peatland subsidence. Further, artificially drained peatlands cause disproportionally high greenhouse gas emissions.

Rewetting peatlands may solve many of the problems related to artificial drainage but is rarely an option because of loss of agricultural land. New management strategies, in which the rewetting of peatland is combined with agricultural use, the so-called 'paludiculture', might be an alternative for sustainable landscape management. A mosaic of paludiculturally used peatlands and peatlands restored primarily for nature conservation purposes, may be the future of multifunctional and sustainably managed peatland landscapes.

As we are just at the beginning of implementing paludicultures, an understanding of the biogeochemistry and ecology of these novel ecosystems is still largely lacking. This special issue aims to contribute to a better understanding of the ecosystem functioning and the underlying processes in rewetted peatlands. Most of these contributions have been presented at the International Wetscapes Conference, held 10-13 September 2019 in Rostock, Germany.

An improved understanding of rewetted peatlands, and especially fens, is the basis for a sustainable use of wet landscapes. How an inter- and multidisciplinary approach can foster better knowledge and-based on this - the sustainable use of peatlands is the topic of the first contribution [1].

In fens, peat is mainly produced by herbaceous plants as "displacement peat", rather than growing moss peat that is more typical for bogs. As roots are important contributors in fen peat, their study is especially important in displacement peats. However, it is also difficult, as methods used in mineral soils, e.g., computer tomography, do not work in peat due to the large water contents. Gribbe et al. [2] present a new low-budget method for creating 3D models of root systems in peat and for estimating root volumes.

The relative contribution of litter formed by aboveground plant parts and of roots to the buildup of displacement peat is still unknown. Also, the rate of peat formation after rewetting has not been determined so far. The third paper of the special issue [3] deals with the use of micro- and macro-remains of plants for answering questions on the history of peat formation and degradation, and peat neoformation after rewetting.

Analyses of micro- and macro-remains were-in combination with other analyses-used in the next paper [4] to reconstruct losses and gains of peat (carbon) during the history of drainage and rewetting of a percolation fen. This paper shows that an uptake of carbon from the atmosphere into 
peat indeed is possible after rewetting, but in terms of climate change it is much less important than avoiding the emission of greenhouse gases.

Potential long-term influences of rewetting on phosphorus species were analyzed by Negassa et al. [5] using traditional chemical and advanced spectroscopic methods. This indicated that rewetting could result in larger proportions of organic phosphorus and stable phosphorus fractions in the surface horizons of rewetted fens, compared to their degraded counterparts.

The final paper of the special issue deals with the influences of rewetting on emissions of methane and nitrous oxide from nutrient-rich extracted peatlands [6]. The authors report emissions along water level gradients and give recommendations for rewetting of extracted peatlands that lead to reduced emissions.

We thank all authors who have submitted their manuscripts to this special issue on Understanding the Ecology of Restored Fen Peatlands for Protection and Sustainable Use, all WETSCAPES members and participants of the WETSCAPES Conference who gave rise to this special issue and all reviewers and especially journal editors for their engagement and concentrated work during the review process.

Funding: We thank the following funders: The WETSCAPES subprojects led be this editorial's authors were funded by the European Social Fund (ESF) and the Ministry of Education, Science and Culture of Mecklenburg-Western Pomerania (ESF/14-BM-A55-0027/16 and ESF/14-BM-A55-0029/16). The WETSCAPES Conference was furthermore supported by funding from the German Science Foundation (DFG) and the International Union of Soil Sciences (IUSS Stimulus Fund).

Acknowledgments: We gratefully acknowledge the skillful administration of the WETSCAPES project by Franziska Schmacka.

Conflicts of Interest: The authors declare no conflict of interest.

\section{References}

1. Jurasinski, G.; Ahmad, S.; Anadon-Rosell, A.; Berendt, J.; Beyer, F.; Bill, R.; Blume-Werry, G.; Couwenberg, J.; Günther, A.; Joosten, H.; et al. From Understanding to Sustainable Use of Peatlands: The WETSCAPES Approach. Soil Syst. 2020, 4, 14. [CrossRef]

2. Gribbe, S.; Blume-Werry, G.; Couwenberg, J. Digital, Three-Dimensional Visualization of Root Systems in Peat. Soil Syst. 2020, 4, 13. [CrossRef]

3. Michaelis, D.; Mrotzek, A.; Couwenberg, J. Roots, Tissues, Cells and Fragments-How to Characterize Peat from Drained and Rewetted Fens. Soil Syst. 2020, 4, 12. [CrossRef]

4. Mrotzek, A.; Michaelis, D.; Günther, A.; Wrage-Mönnig, N.; Couwenberg, J. Mass Balances of a Drained and a Rewetted Peatland: On Former Losses and Recent Gains. Soil Syst. 2020, 4, 16. [CrossRef]

5. Negassa, W.; Michalik, D.; Klysubun, W.; Leinweber, P. Phosphorus Speciation in Long-Term Drained and Rewetted Peatlands of Northern Germany. Soil Syst. 2020, 4, 11. [CrossRef]

6. Jordan, S.; Strömgren, M.; Fiedler, J.; Lode, E.; Nilsson, T.; Lundin, L. Methane and Nitrous Oxide Emission Fluxes Along Water Level Gradients in Littoral Zones of Constructed Surface Water Bodies in a Rewetted Extracted Peatland in Sweden. Soil Syst. 2020, 4, 17. [CrossRef] 